\title{
ARTICLE \\ Floristic Inventory and Evaluation of Carbon Sequestration Potential of the Misomuni Forest Massif, Kikwit City (Democratic Republic of the Congo)
}

\author{
Masens Da-Musa Y.B. ${ }^{1 *}$ Briki K. Cyril $^{2}$ Masens Mandung ${ }^{3}$ Koto-Te-Nyiwa Ngbolua ${ }^{1}$ \\ 1. Department of Biology, Faculty of Science, University of Kinshasa, Kinshasa, Democratic Republic of Congo \\ 2. University of Kikwit, Kikwit, Democratic Republic of Congo \\ 3. Lumbi Higher Institute of Medical Techniques, Lumbi, Democratic Republic of Congo
}

\section{ARTICLE INFO}

Article history

Received: 2 August 2021

Accepted: 25 August 2021

Published Online: 7 September 2021

Keywords:

Forest ecosystem

Plant biodiversity

Carbon sequestration

Reducing Emissions from Deforestation and

Forest Degradation project

Democratic Republic of the Congo

\begin{abstract}
The aim of this study was to inventory plant biodiversity and to evaluate the carbon sequestration potential of the Misomuni forest massif. An inventory of all trees with diameter at breast height $(\mathrm{dbh}) \geq 10 \mathrm{~cm}$ measured at $1.30 \mathrm{~m}$ height was performed. The aerial biomass (AGB) was used for estimating the stored $\mathrm{CO}_{2}$ and its carbon equivalent. 88 plant species belonging to 71 genera and 32 families were inventoried. Fabaceae family displayed the highest number of species and genera. The highest basal area values were displayed by Scorodophloeus zenkeri $\left(7.34 \pm 2.45 \mathrm{~m}^{2} / \mathrm{ha}\right)$, Brachystegia laurentii $\left(5.82 \pm 1.94 \mathrm{~m}^{2} / \mathrm{ha}\right)$, Entandrophragma utile $(5.28 \pm$ $\left.1.94 \mathrm{~m}^{2} / \mathrm{ha}\right)$, Pentadesma butyracea $\left(4.53 \pm 1.51 \mathrm{~m}^{2} / \mathrm{ha}\right)$. The highest values of stored carbon and their carbon equivalent were observed in Pentadesma butyracea $(15.13 \pm 5.00$ and $50.55 \pm 16.85 \mathrm{t} / \mathrm{ha})$, Picralima nitida $(7.02 \pm$ 2.34 and $23.66 \pm 7.88 \mathrm{t} / \mathrm{ha})$, Strombosia tetandra $(6.56 \pm 2.18$ and $22.10 \pm$ $7.36 \mathrm{t} / \mathrm{ha}$ ). The Misomuni forest massif is thus much floristically diversified and plays a significant role in the sequestration of $\mathrm{CO}_{2}$. The total AGB of the inventoried trees is $183.78 \pm 61.26 \mathrm{t} / \mathrm{ha}$ corresponding to stored carbon and carbon equivalent of $96.63 \pm 32.21 \mathrm{t} / \mathrm{ha}$ and $289.92 \pm 96.64 \mathrm{t} / \mathrm{ha}$ respectively. The protection of this ecosystem is highly needed for combatting climatic changes at local, national and regional scales and for the conservation biodiversity habitat.
\end{abstract}

The Misomuni forest massif is located in the south of Kikwit city (Kwilu province) in the West part of DRC. Actually, the observed loss of biological diversity in this region is essentially linked to human activity. Indeed, the above-mentioned massif is currently fragmented into several forest islands because of the numerous excessive anthropic activities undertaken in this phytocenosis. Although, three forest islands still retain certain homogeneity due to their particular status as "farms"; so

*Corresponding Author:

Masens Da-Musa Y.B.,

Department of Biology, Faculty of Science, University of Kinshasa, Kinshasa, Democratic Republic of Congo;

Email:jpngbolua@unikin.ac.cd 
providing service such as microclimate regulation and supporting service like photosynthesis, soils formation and nutrient cycling ${ }^{[2]}$. The geographical coordinates of these patches are practically the same, although the Mbala Ding portion is located $\pm 3 \mathrm{~km}$ from two other patches and separated from them by an anthropogenic savanna. These coordinates are: $05^{\circ} 08^{\prime}$ south latitude, $18^{\circ} 58^{\prime}$ East longitude, and 140 to $458 \mathrm{~m}$ of elevation ${ }^{[3]}$. It will be necessary to evaluate the quantity of carbon stored by this phytocenosis and that released following the destruction of the trees which compose this forest massif from the manufacture of charcoal. This would allow in the near future evaluating the impact of the degradation of this plant formation on the climate change currently observed in this region of the country. Indeed, in recent years, there has been an increased demand for traditional bioenergy from the populations of the region concerned, because there is no or little electricity in many areas of our country ${ }^{[4]}$. To confirm this situation, it is necessary to travel along the National Highway 1 from Kinshasa to km 622 after the town of Kikwit to realize this. Many thousands of bags of embers are spread out along this main road beyond view. These products are the result of the destruction or indiscriminate deforestation of both forest and savannah ecosystems (shrubby savannahs, woodlands, etc.). The combustion of this traditional bioenergy releases tons and tons of $\mathrm{CO}_{2}$, a greenhouse gas, into the atmosphere ${ }^{[5]}$. The aim of this study was to inventory plant biodiversity and to evaluate the carbon sequestration potential of the Misomuni forest massif. Indeed, assessing carbon sequestration in such forest ecosystem is required to supply information to monitor, report and verify for reducing deforestation and forest degradation (REDD) program as well as for biodiversity conservation in order to ensure ecosystem functioning.

\section{Material and Methods}

The Misomuni forest massif, currently divided into several forest islands including Kisalangundu, Mbala Ding and Mambala, is located at least $30 \mathrm{~km}$ south of the town of Kikwit on the Batsamba and/or Mukulu road (Figure 1).

It is located geographically between $5^{\circ} 08^{\prime}$ south latitude and $18^{\circ} 58^{\prime}$ 'west longitude and an altitude varying between 140 and $458 \mathrm{~m}$. Floristic inventory and dendrometric measurements were conducted within these islands (one-hectare plot by island/site i.e. 3 ha in total). The inventory was based on rectangular plots measuring $100 \mathrm{~m}$ in length and $20 \mathrm{~m}$ in width (i.e. an area of 0.2 ha), joined together, and laid out along parallel inventory paths. For this purpose, a network of five plots was set up along the paths. Only trees with dbh measured at 1.30 $\mathrm{m}$ from the ground and $\geq 10 \mathrm{~cm}$ were considered. All specimens of inventoried trees and shrubs were identified according to APG versions II, III, and IV. The ecological spectra (biological type, diaspora type and foliar type)

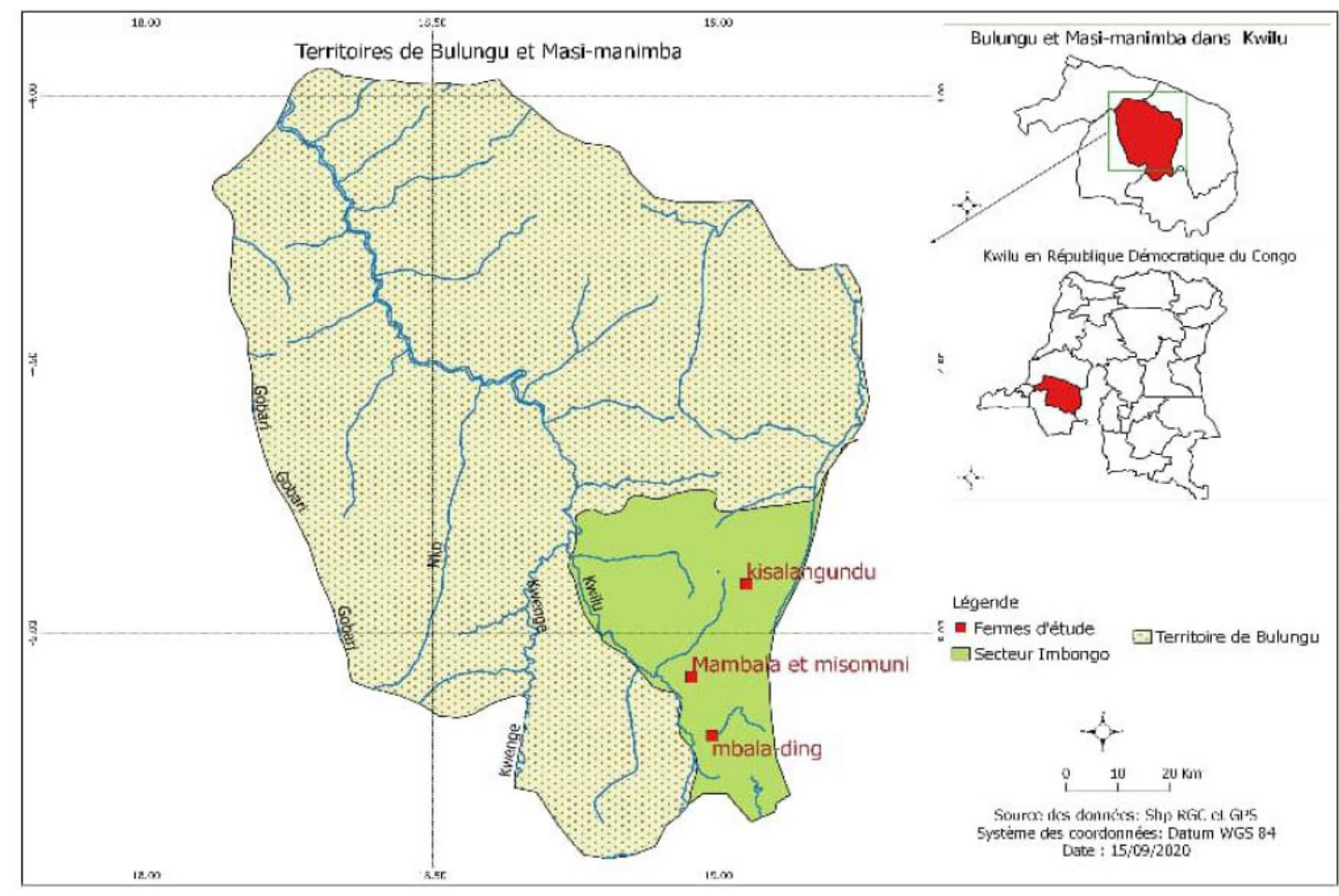

Figure 1. Location of the study sites 
were determined using the Raunkiaer classification as previously reported ${ }^{[6-10]}$. The Raunkiaer system was used to determine the types of leaf size ${ }^{[11-15]}$. The morphological classification of Dansereau \& Lems and the ecomorphological classification of Molinier \& Mùller were used to determine the types of dissemination ${ }^{[16-18]}$. The phytogeographical distribution types defined in this study were established according to Lebrun as reported by several authors for tropical Africa region ${ }^{[17,19-22]}$. The determination of ecosociological groups was carried out according to the research of Lubini ${ }^{[23]}$. The calculations of (AGB), stored carbon (CSe), carbon equivalent (EqC) and basal area (BA or $\mathrm{G})$ were carried out according to the following equations as previously reported ${ }^{[24-28]}$.

$A G B=\operatorname{Exp}(-0.37+0.333 * \ln (D B H)+$

$0.933 \ln (D B H)^{2}-0.122 * \ln (\mathrm{DBH})$

$C S e=0.47 * A G B$

$E q C=3.667 * C S e$

$G=\frac{\pi}{4 S} \sum_{i=1}^{n} d i^{2}$

Where DBH is the diameter at breast height; $\mathrm{S}$ is the surface of the plot; di is the diameter of the tree $I, n$ is the total number of trees with $(\mathrm{dbh}) \geq 10 \mathrm{~cm}$ measured at 1.30 $\mathrm{m}$ height; $\mathrm{Ht}$ is the total height; $\mathrm{d}$ is the specific density of the wood.

The Microsoft Excel 2007 and IBM SPSS statistics version 14.0 software packages were used for data analysis while the allometric the equations were used to evaluate the correlation between some parameters (AGB and density, AGB and dbh, AGB and G, etc.).

\section{Results}

88 different plant species have been listed and identified overall. These species are divided into 71 genera, and 32 families (Table 1). Fabaceae is the group with the highest number of species and genera. Indeed, this group contains 24 species in total, or $27.27 \%$ and 15 genera, or $21.43 \%$. It is very distantly followed by Sapotaceae; Clusiaceae and Myristicaceae with respectively 6; 4 and 4 species each, which is to say $6.82 ; 4.54$ and $4.54 \%$. Eight families have 3 species each, i.e. 24 species in all. These are Annonaceae; Apocynaceae; Chrysobalanaceae; Malvaceae; Meliaceae; Moraceae; Strombosiaceae and Ulmaceae. As for the twelve remaining families, they are monospecific. The genera Celtis, Chrysophyllum and Distemonanthus each have three different plant species. They are followed by twelve others with 2 species each. In terms of number of individuals, Scorodophloeus zenkeri Harms, Staudtia kamerunensis Warb. and Anonidium mannii (Oliv.) Engl. \& Diels have a high number of plants, respectively $152 \pm 50.67$ trees/ha; 119 \pm 39.67 trees/ha and $108 \pm 36.00$ trees/ha. Six species are weakly represented. These include Entandrophragma angolense (Welw.) C.DC. (1 tree/ha); Celtis tenuifolia Nutt. (1 tree/ha). The numerical number of trees varying between 10 and 28 was observed in 11 species, including Petersianthus macrocarpus (P.Beauv.) Liben $(85 \pm 28.33$ trees/ha), Maranthes chrysophylla (Oliv.) Prance ex F.White ( $65 \pm 21.66$ trees/ha), Pterocarpus mildbraedii Harms (59 \pm 19.66 trees/ha), Duboscia viridiflora (K.Schum.) Mildbr. ( $34 \pm 11.33$ trees/ha), etc.

Table 1. List of identified plant species and their ecological characteristics

\begin{tabular}{|c|c|c|c|c|c|}
\hline Botanical name & Family & Phyto distribution & Biological type & Diaspora type & Foliar type \\
\hline Albizia adiantifolia (Schumach) W.Wight & Fabaceae & GC & $\mathrm{MgPh}$ & Bal & Mi \\
\hline Albizia gummifera Var. (Schum W.F.Wight.) & Fabaceae & GC & $\mathrm{MsPh}$ & Bal & $\mathrm{Me}$ \\
\hline Amphimas ptercarpoïdes Harmas & Fabaceae & $\mathrm{GC}$ & $\mathrm{MsPh}$ & Bal & $\mathrm{Me}$ \\
\hline Angylocallyx marginervatus(Baker) Baker.F & Fabaceae & GC & $\mathrm{MsPh}$ & Bal & $\mathrm{Me}$ \\
\hline Anisophyllea polyneura Engl. & Anisophylleaceae & CG & $\mathrm{MsPh}$ & Sar & $\mathrm{Me}$ \\
\hline Anodium mannii (Oliv.)Engl et Diels & Annonaceae & GC & $\mathrm{MsPh}$ & Sar & Ma \\
\hline Anthocleista shweinfurthii Gilg. & Gentianaceae & GC & $\mathrm{McPh}$ & Sar & Ma \\
\hline Anthrocaryon micraster De Wild. & Anacardiaceae & GC & $\mathrm{MsPh}$ & Sar & $\mathrm{Me}$ \\
\hline Antrocaryon klaineanum Pierre & Anacardiaceae & $\mathrm{GC}$ & $\mathrm{MsPh}$ & Sar & $\mathrm{Me}$ \\
\hline Aubrecavillea kerstingii Brenan & Fabaceae & $\mathrm{CG}$ & $\mathrm{MsPh}$ & Pte & $\mathrm{Me}$ \\
\hline Brachystegia laurentii Louis ex.Hoyle & Fabaceae & $\mathrm{CG}$ & $\mathrm{MgPh}$ & Bal & $\mathrm{Me}$ \\
\hline Brachystegia sp (De Wild.) Louis ex Hoyle. & Fabaceae & $\mathrm{CG}$ & $\mathrm{MgPh}$ & Bal & $\mathrm{Me}$ \\
\hline
\end{tabular}




\begin{tabular}{|c|c|c|c|c|c|}
\hline Botanical name & Family & Phyto distribution & Biological type & Diaspora type & Foliar type \\
\hline Brenania brieyi Petit & Rubiaceae & $\mathrm{CG}$ & $\mathrm{MsPh}$ & Sar & $\mathrm{Me}$ \\
\hline Canarium schweinfurthii Engl. & Burseraceae & $\mathrm{CG}$ & $\mathrm{MsPh}$ & Sar & $\mathrm{Me}$ \\
\hline $\begin{array}{c}\text { Canthium arnoldianum (De Wild.et Th.Dur) } \\
\text { Hepper }\end{array}$ & Rubiaceae & $\mathrm{CG}$ & $\mathrm{MgPh}$ & Sar & $\mathrm{Me}$ \\
\hline Celtis sp & Ulmaceae & GC & $\mathrm{MsPh}$ & Sar & $\mathrm{Me}$ \\
\hline Celtis tenuifolia Nutt. & Ulmaceae & $\mathrm{CG}$ & $\mathrm{MsPh}$ & Sar & $\mathrm{Mi}$ \\
\hline Celtis zenkzri Engl. & Ulmaceae & $\mathrm{GC}$ & $\mathrm{MsPh}$ & Sar & $\mathrm{Me}$ \\
\hline Chrysophyllum africanum Pierre. & Sapotaceae & $\mathrm{CG}$ & $\mathrm{MgPh}$ & Sar & $\mathrm{Me}$ \\
\hline Chysophyllum lacourtianum De Wild. & Sapotaceae & $\mathrm{CG}$ & $\mathrm{MgPh}$ & Sar & $\mathrm{Me}$ \\
\hline Coelocaryon preussii Warb. & Myristicaceae & $\mathrm{CG}$ & $\mathrm{MsPh}$ & Sar & $\mathrm{Me}$ \\
\hline Cola lateritia K.Schum. & Malvaceae & CG & $\mathrm{MsPh}$ & Sar & $\mathrm{Me}$ \\
\hline Detarium macrocarpus Guill\& perr. & Fabaceae & $\mathrm{CG}$ & $\mathrm{MgPh}$ & Sar & $\mathrm{Me}$ \\
\hline Diospyros crassiflora Hiern. & Ebenaceae & $\mathrm{BGC}$ & $\mathrm{MsPh}$ & Sar & $\mathrm{Me}$ \\
\hline Distemonanthus benthamianus Baill & Fabaceae & $\mathrm{CG}$ & $\mathrm{MsPh}$ & Sar & $\mathrm{Me}$ \\
\hline Distemonathus macrophylla Baill. & Fabaceae & $\mathrm{GC}$ & $\mathrm{MsPh}$ & Sar & $\mathrm{Me}$ \\
\hline Duboscia viridiflora Boca. & Malvaceae & $\mathrm{CG}$ & $\mathrm{MsPh}$ & Sar & $\mathrm{Me}$ \\
\hline Enanthia clorantha Oliv. & Annonaceae & GC & $\mathrm{MsPh}$ & Sar & $\mathrm{Me}$ \\
\hline Entandrophragma angolense (Deilt.) A Chev & Meliaceae & $\mathrm{GC}$ & $\mathrm{MgPh}$ & Sar & $\mathrm{Me}$ \\
\hline Entandrophragma utile (Dawe et Sprague) & Melaceae & $\mathrm{GC}$ & $\mathrm{MgPh}$ & Pte & $\mathrm{Me}$ \\
\hline Eriocoelum macrocarpum & Sapindaceae & $\mathrm{GC}$ & $\mathrm{MsPh}$ & Pte & $\mathrm{Me}$ \\
\hline Erismadelphus exsul Mildbr. & Vochysiaceae & $\mathrm{GC}$ & $\mathrm{MsPh}$ & Pte & $\mathrm{Me}$ \\
\hline Erythroxylum mannii Oliv. & Erythroxylaceae & CG & $\mathrm{MsPh}$ & Sar & $\mathrm{Me}$ \\
\hline Ficus mucuso Welw. Ex.Ficalho & Moraceae & At & $\mathrm{MsPh}$ & Sar & $\mathrm{Me}$ \\
\hline Furtumia elastica (Preuss) Staf & Apocynaceae & $\mathrm{GC}$ & $\mathrm{MsPh}$ & $\mathrm{Scl}$ & $\mathrm{Me}$ \\
\hline Gambeya beguei Aubrev. \& peller & Sapotaceae & $\mathrm{CG}$ & $\mathrm{MsPh}$ & Sar & $\mathrm{Me}$ \\
\hline Gilbertiodendron dewevrei $\mathrm{L}$. & Fabaceae & $\mathrm{GC}$ & $\mathrm{MgPh}$ & Sar & $\mathrm{Me}$ \\
\hline Guarea thompsonii (A. Chev) Pellegr. & Meliaceae & $\mathrm{GC}$ & $\mathrm{MgPh}$ & Sar & $\mathrm{Me}$ \\
\hline Homalium sp & Salicaceae & $\mathrm{GC}$ & $\mathrm{MsPh}$ & Sar & $\mathrm{Me}$ \\
\hline Irvingia robur Mildbr. & Irvingiaceae & $\mathrm{CG}$ & $\mathrm{MsPh}$ & Sar & $\mathrm{Me}$ \\
\hline Lovoa trichiliodes Harms & Meliaceae & $\mathrm{GC}$ & $\mathrm{MsPh}$ & $\mathrm{Scl}$ & $\mathrm{Me}$ \\
\hline Manilkara sp & Sapotaceae & $\mathrm{CG}$ & $\mathrm{MgPh}$ & Sar & $\mathrm{Me}$ \\
\hline Maranthes chrysophylla (Oliv) Prance & Chrysobalanaceae & $\mathrm{CG}$ & $\mathrm{MsPh}$ & Sar & $\mathrm{Me}$ \\
\hline Maranthes glabra (Oliv) Prance & Chrysobalanaceae & CG & $\mathrm{MsPh}$ & Sar & $\mathrm{Me}$ \\
\hline Mildbraediodendrom excelsum Harms & Fabaceae & CG & $\mathrm{MsPh}$ & Bal & $\mathrm{Me}$ \\
\hline Milicia excelsa (Welw.) Berg. & Moraceae & $\mathrm{GC}$ & $\mathrm{MgPh}$ & Sar & $\mathrm{Me}$ \\
\hline Musanga cecropioides Roxb. Br. & Urticaceae & $\mathrm{GC}$ & $\mathrm{MgPh}$ & Sar & $\mathrm{Me}$ \\
\hline Nesogordonia papaverifera (A. Chev.) Copur & Malvaceae & $\mathrm{GC}$ & $\mathrm{MsPh}$ & Sar & $\mathrm{Me}$ \\
\hline Omphalocarpum elatu Miers & Sapotaceae & $\mathrm{GC}$ & $\mathrm{MgPh}$ & Sar & $\mathrm{Me}$ \\
\hline Oncoba welwitschii & Salicaceae & $\mathrm{GC}$ & $\mathrm{McPh}$ & Sar & $\mathrm{Me}$ \\
\hline Ongokea gore Pierre & Olacaceae & $\mathrm{GC}$ & $\mathrm{MgPh}$ & Sar & $\mathrm{Me}$ \\
\hline Pachyelasma mannii Sabine & Fabaceae & $\mathrm{GC}$ & $\mathrm{MgPh}$ & Bal & $\mathrm{Me}$ \\
\hline
\end{tabular}




\begin{tabular}{|c|c|c|c|c|c|}
\hline Botanical name & Family & Phyto distribution & Biological type & Diaspora type & Foliar type \\
\hline Pachyelasma tessmannii Harms & Fabaceae & $\mathrm{GC}$ & $\mathrm{MgPh}$ & Bal & $\mathrm{Me}$ \\
\hline Pachypodianthium staudtii (Engl.et Diels) & Annonaceae & $\mathrm{CG}$ & $\mathrm{MsPh}$ & Sar & $\mathrm{Me}$ \\
\hline Panda oelosa Pierre & Pandaceae & $\mathrm{GC}$ & $\mathrm{McPh}$ & Sar & $\mathrm{Me}$ \\
\hline Parinari excelsa Sarbine & Chrysobalanaceae & $\mathrm{CG}$ & $\mathrm{MgPh}$ & Sar & $\mathrm{Me}$ \\
\hline Pentaclethra macrophylla Benth. & Fabaceae & GC & $\mathrm{MsPh}$ & Sar & $\mathrm{Me}$ \\
\hline Pentadesma butyracea Sabine & Clusiaceae & $\mathrm{FC}$ & $\mathrm{MsPh}$ & Sar & $\mathrm{Me}$ \\
\hline Pentadesma excelliana Staner. & Clusiaceae & $\mathrm{FC}$ & $\mathrm{MsPh}$ & Sar & $\mathrm{Me}$ \\
\hline Pentadesma grandiflora Staner & Clusiaceae & $\mathrm{FC}$ & $\mathrm{MsPh}$ & Sar & $\mathrm{Me}$ \\
\hline Petersianthus macrocarpus Beauv. Liben. & Lecythidaceae & $\mathrm{GC}$ & $\mathrm{MgPh}$ & Sar & $\mathrm{Me}$ \\
\hline Picralima nitida (Baill.) Urb. & Apocynaceae & GC & $\mathrm{MgPh}$ & Sar & $\mathrm{Me}$ \\
\hline Poga oleosa Gurke & Rhizophoraceae & GC & $\mathrm{MsPh}$ & Sar & $\mathrm{Me}$ \\
\hline Polyscias fulva (Hiern) Harms & Araliaceae & $\mathrm{CG}$ & $\mathrm{MgPh}$ & Pte & $\mathrm{Me}$ \\
\hline Prioria balsamifera Vern. & Fabaceae & GC & $\mathrm{MgPh}$ & Bal & $\mathrm{Me}$ \\
\hline Pterocarpus mildbraedii Taub. & Fabaceae & $\mathrm{GC}$ & $\mathrm{MsPh}$ & Pte & $\mathrm{Me}$ \\
\hline Pterocarpus tinctorius Hams & Fabaceae & At & $\mathrm{MgPh}$ & Sar & $\mathrm{Me}$ \\
\hline Pycnanthus angolensis Warb. & Myristicaceae & GC & $\mathrm{MsPh}$ & Sar & $\mathrm{Me}$ \\
\hline Sacoglottis gabonensis L.F.Baill. & Humiriacea & $\mathrm{GC}$ & $\mathrm{MsPh}$ & Sar & $\mathrm{Me}$ \\
\hline Santiria trimera (Oliv.) Aubreu. & Burseraceae & $\mathrm{CG}$ & $\mathrm{MsPh}$ & Sar & $\mathrm{Me}$ \\
\hline Schrebera arborea Welw. & Oleaceae & At & $\mathrm{MsPh}$ & Pte & $\mathrm{Me}$ \\
\hline Scorodophloeus zenkeri Harms & Fabaceae & $\mathrm{CG}$ & $\mathrm{MgPh}$ & Bal & $\mathrm{Me}$ \\
\hline Scyphocephallium mannii W.orb. & Myristicaceae & GC & $\mathrm{MsPh}$ & Sar & $\mathrm{Me}$ \\
\hline Staudtia kamerunensis Warb. & Myristicaceae & $\mathrm{CG}$ & $\mathrm{MsPh}$ & Sar & $\mathrm{Me}$ \\
\hline Strombosia pustulata Hook.F. & Olacaceae & $\mathrm{CG}$ & $\mathrm{MsPh}$ & Sar & $\mathrm{Me}$ \\
\hline Strombosia tetandra Hook.F. & Olacaceae & CG & $\mathrm{MsPh}$ & Sar & $\mathrm{Me}$ \\
\hline Symphonnia globulifera L.F. & Clusiaceae & At & $\mathrm{MsPh}$ & Sar & $\mathrm{Me}$ \\
\hline Synsepalum msolo (Engl.) T.D.Penn. & Sapotaceae & $\mathrm{GC}$ & $\mathrm{MsPh}$ & Sar & $\mathrm{Me}$ \\
\hline Tabernaemontana crassa Benth. & Apocynaceae & $\mathrm{GC}$ & $\mathrm{McPh}$ & Sar & $\mathrm{Me}$ \\
\hline Tessmania africana Harms. & Fabaceae & $\mathrm{GC}$ & $\mathrm{MgPh}$ & Bal & $\mathrm{Me}$ \\
\hline Trilepisium madagascariense DC. & Moraceae & $\mathrm{GC}$ & $\mathrm{MsPh}$ & Sar & $\mathrm{Me}$ \\
\hline Vitex congolensis Dewild et Th. Dur. & Verbenaceae & $\mathrm{GC}$ & $\mathrm{MsPh}$ & Sar & $\mathrm{Me}$ \\
\hline Vitex grandifolia(Gurk) W.piep & Verbenaceae & $\mathrm{CG}$ & $\mathrm{MsPh}$ & Sar & $\mathrm{Me}$ \\
\hline Vitex welwitschii Gurke & Verbenaceae & $\mathrm{GC}$ & $\mathrm{MsPh}$ & Sar & $\mathrm{Me}$ \\
\hline
\end{tabular}

The highest basal area (BA) and above-ground biomass (AGB) values were obtained for the following plant species (Figure 2): Scorodophloeus zenkeri Harms (7.34 $\pm 2.45 \mathrm{~m}^{2} / \mathrm{ha}$ ), Brachystegia laurentii (De Wild.) Hoyle $\left(5.82 \pm 1.94 \mathrm{~m}^{2} / \mathrm{ha}\right)$, Entandrophragma utile (Dawe \& Sprague) Sprague $\left(5.28 \pm 1.94 \mathrm{~m}^{2} / \mathrm{ha}\right)$, Pentadesma butyracea Sabine $\left(4.53 \pm 1.51 \mathrm{~m}^{2} / \mathrm{ha}\right)$ (for BA) and Pentadesma butyracea Sabine (31.44 $\pm 10.48 \mathrm{t} / \mathrm{ha})$, Picralima nitida (Stapf) T.Durand \& H.Durand (14.95 \pm 4.98 t/ha), Antrocaryon micraster A.Chev. \& Guillaumin
(9.56 \pm 3.19 t/ha), Synsepalum msolo (Engl.) T.D.Penn. $(6.96 \pm 2.32 \mathrm{t} / \mathrm{ha})$, Poga oleosa Pierre $(6.36 \pm 2,12 \mathrm{t} / \mathrm{ha})$, Entandrophragma utile (Dawe \& Sprague) Sprague (5.02 $\pm 1.67 \mathrm{t} / \mathrm{ha}$ ), Brenania brieyi (De Wild.) E.M.A.Petit (4.71 $\pm 1.57 \mathrm{t} / \mathrm{ha})$, Aphanocalyx margininervatus J.Leonard ( $4.61 \pm 1.54 \mathrm{t} / \mathrm{ha})$, etc. for AGB. The highest values of stored carbon and their carbon equivalent were observed in the following species: Pentadesma butyracea Sabine $(15.13 \pm 5.00$ and $50.55 \pm 16.85 \mathrm{t} / \mathrm{ha})$, Picralima nitida (Stapf) T.Durand \& H.Durand (7.02 \pm 2.34 and $23.66 \pm$ 
$7.88 \mathrm{t} / \mathrm{ha})$, Strombosiopsis tetandra Engl. $(6.56 \pm 2.18$ and $22.10 \pm 7.36 \mathrm{t} / \mathrm{ha}$ ), etc. The lowest values of these parameters were obtained in Piptadeniastrum africanum (Hook.f.) Brenan with $0.05 \pm 0.01$ and $0.18 \pm 0.06 \mathrm{t} / \mathrm{ha}$ of sequestered carbon and its carbon equivalent (Figure 2). The average dbh of the species, measured at $1.30 \mathrm{~m}$ above the ground, is $28.82 \mathrm{~m}$, and the highest dbh value was observed in Poga oleosa Pierre with $85.43 \mathrm{~m}$. The lowest dbh value characterizes the species Manilkara $s p$ with $14.17 \mathrm{~m}$. The diametric structure of the sampled trees by class is shown in Figure 3.

It illustrates the density structure (number of stems/ha) according to the dbh classes. The range of dbh classes considered is 15.99 . In total 4 classes of dbh were determined. These include: class $1(10-25.99 \mathrm{~cm})$, class $2(26-41.99 \mathrm{~cm})$, class $3(42-57.99 \mathrm{~cm})$ and $\geq 58 \mathrm{~cm}$. Class 2 has the highest number of stems per hectare, 41 trees, followed by class 1 with 37 stems/ha. Class 4 is sparsely represented at 2 stems/ha.

According to ecological spectra and phytogeographic distribution, Mesophanerophytes represented $69.32 \%$ (Figure 4); Mesophylls (88.64\%: Figure 5) and Sarcochores (68.18\%: Figure 6) while Guinean-Congolese species were the most represented (60.23\%: Figure 7). Table 2 and Figure 8 established the correlation between AGB and BA. From their analysis, it appears that the two compared parameters are positively correlated $\left(\mathrm{R}^{2}>0.75\right.$; $p$ value $<0.05)$.

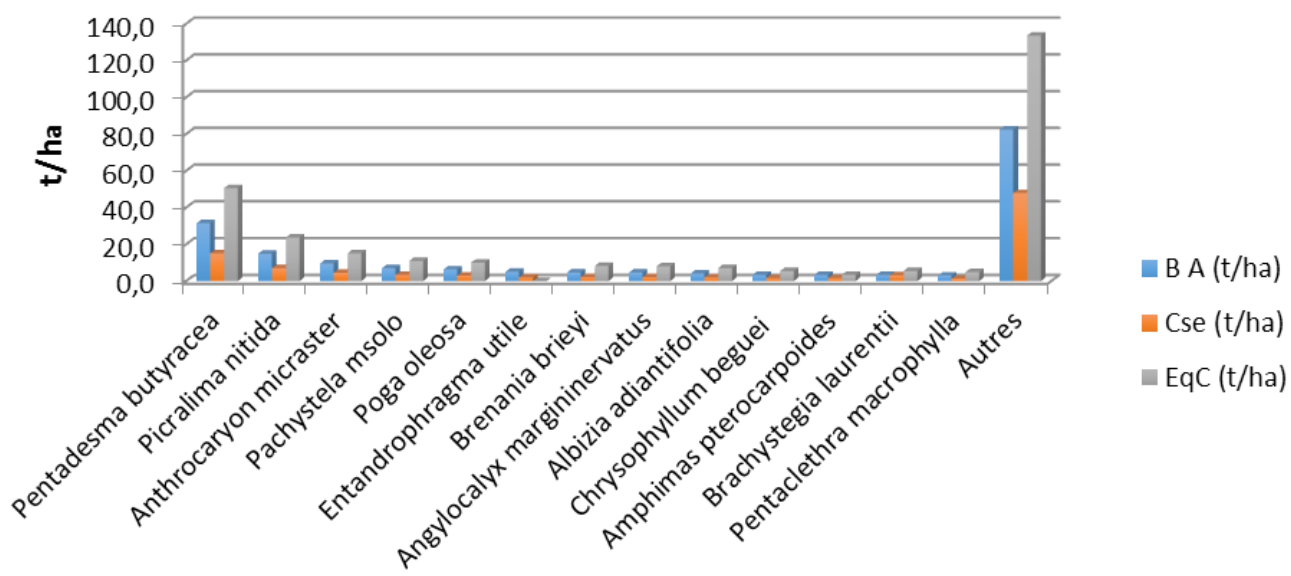

Plant species

Figure 2. Measurement of BA, Cse and EqC

(Legend: $B A=$ Basal area; $C s e=$ Sequestered carbon; $E q C=$ Carbon equivalent)

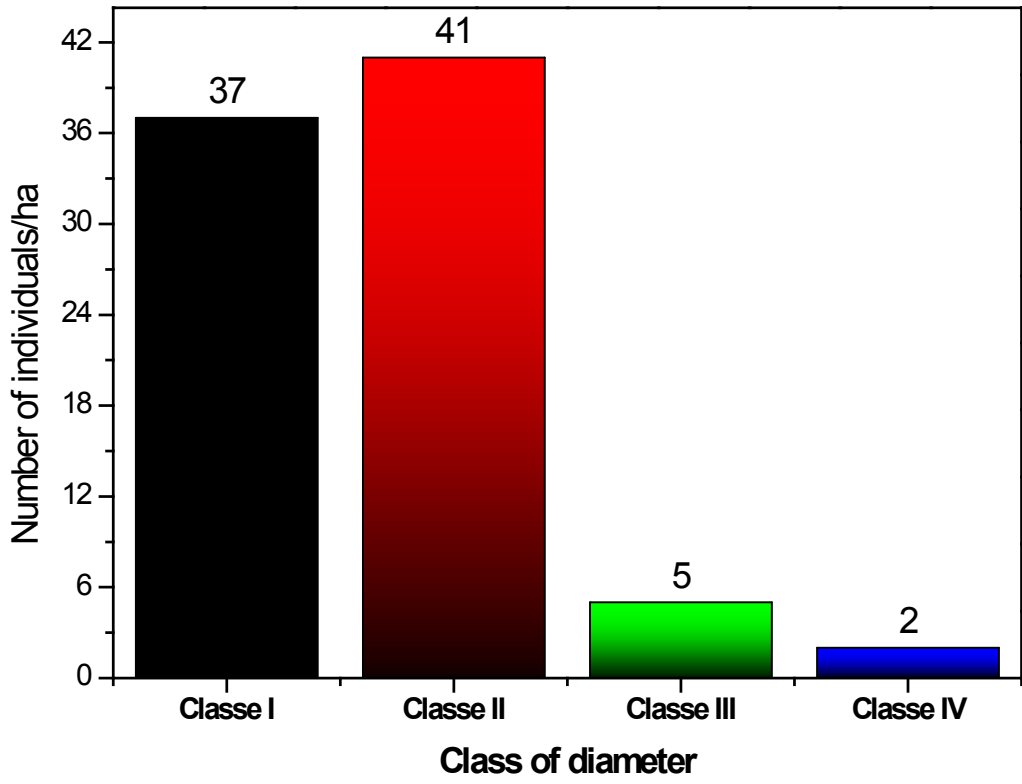

Figure 3. Diameter structure of trees listed by class 


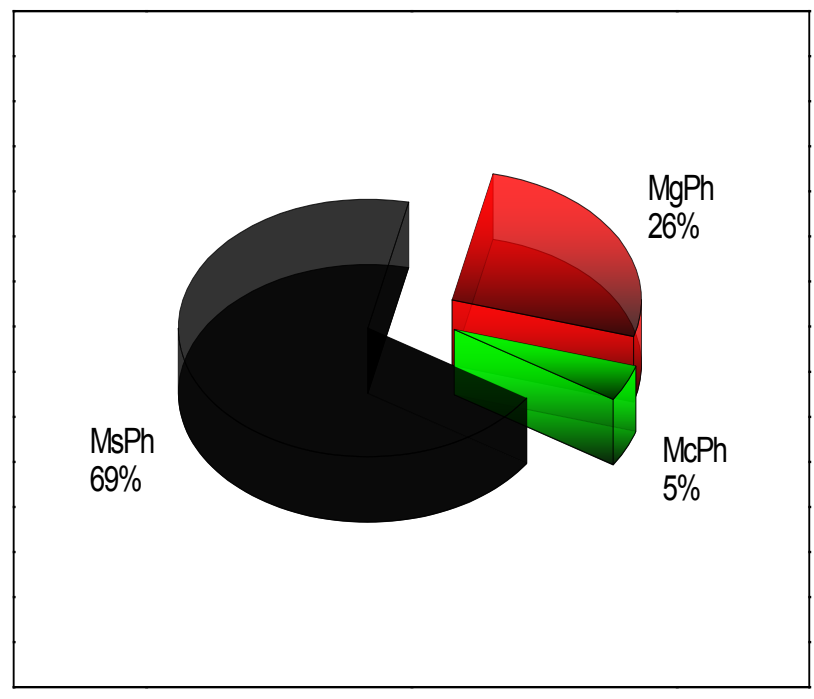

Figure 4. Biological types

(Legend: MsPh: Mesophanerophyte; MgPh: Megaphanerophyte; $\mathrm{McPh}$ : Microphanerophyte)

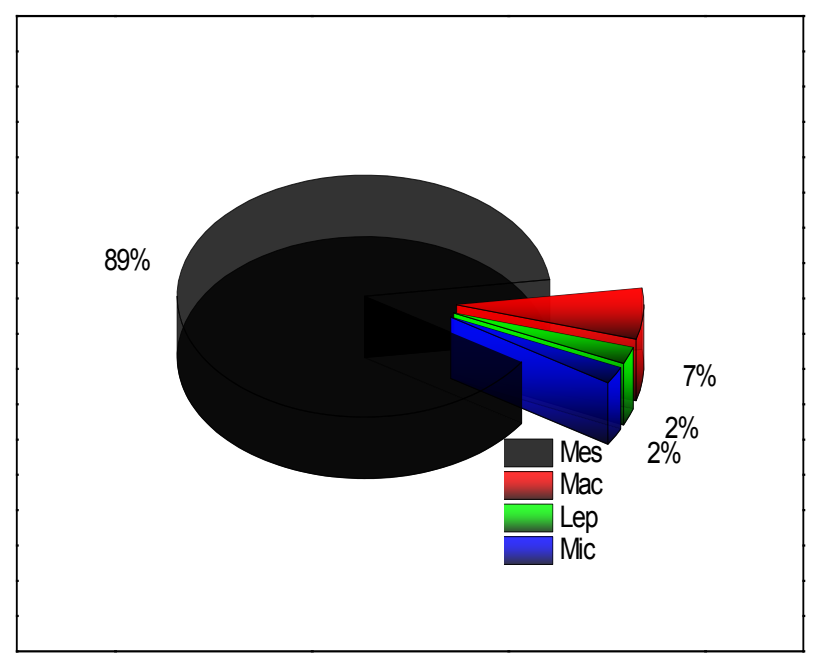

Figure 5. Types of leaf size

(Legend: Mes: Mesophyll; Mac: Macrophyll; Lep: Leptophyll; Mic: Microphyll)

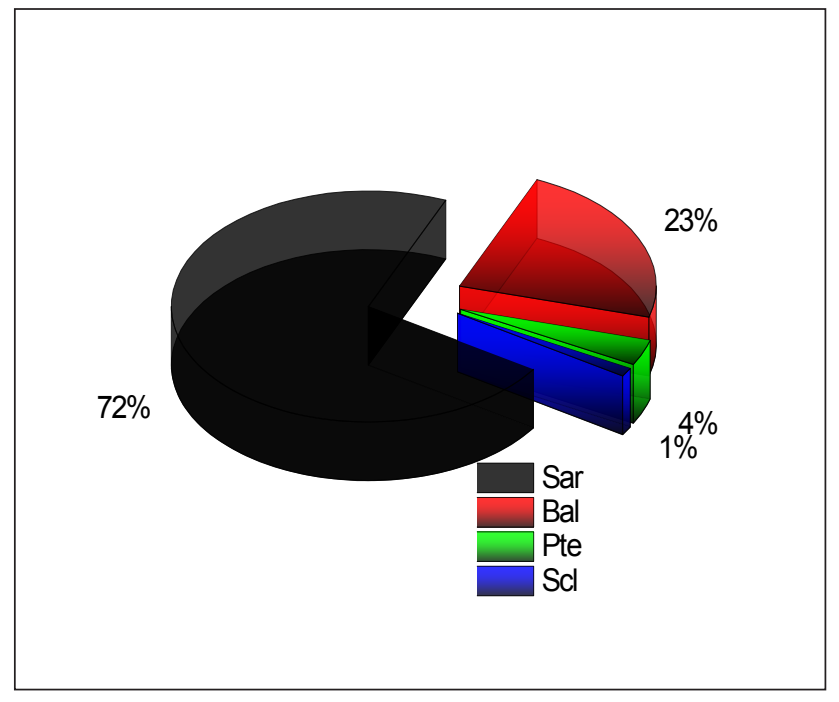

Figure 6. Types of diaspora

(Legend: Sar: Sarcochores; Bal: Ballochores; Pte: Pterochores; Scl: Sclerochores)

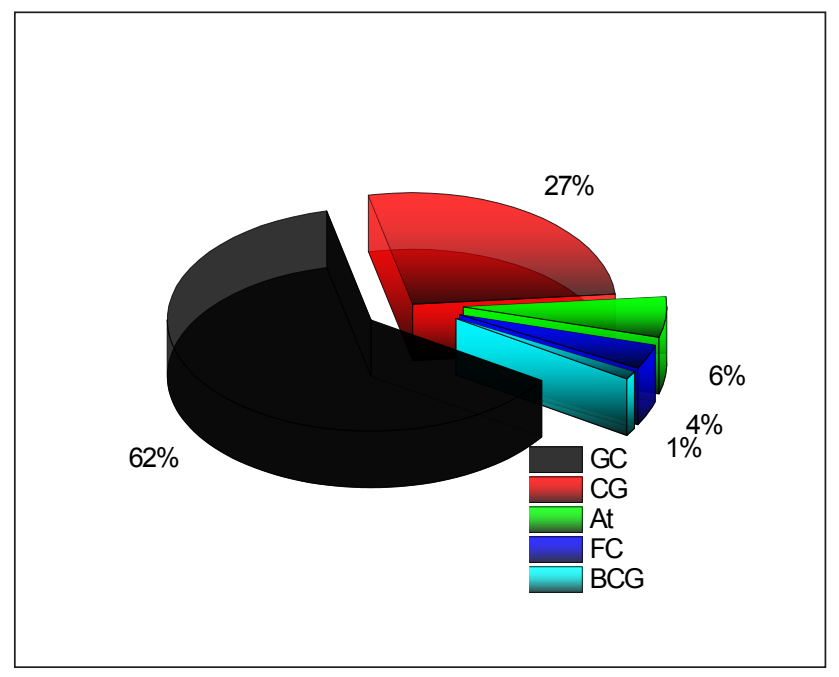

Figure 7. Phytogeographic distribution types

(Legend: GC: Guinean-Congolese species; CG: Central Guinean species; At: Afro-tropical species; FC: Central forester; BCG: Lower Guinean-Congolese species species)

Table 2. Relationship between AGB and basal area

\begin{tabular}{|c|c|c|c|c|c|c|c|c|c|}
\hline \multirow[t]{2}{*}{ Equation } & \multicolumn{5}{|c|}{ Summary of models } & \multicolumn{4}{|c|}{ Estimates of the parameters } \\
\hline & R Square & $\mathrm{F}$ & ddl1 & ddl2 & p-value & Constant & b1 & b2 & b3 \\
\hline Linear & 0,981 & 474,205 & 1 & 33 & 0,000 & 31,383 & 7,399 & & \\
\hline Logarithmic & 0,829 & 39,211 & 1 & 37 & 0,001 & 430,276 & 191,018 & & \\
\hline Quadratic & 0,858 & 424,527 & 2 & 26 & 0,002 & 20,920 & 3,600 & 0,046 & \\
\hline Cubic & 0,798 & 435,374 & 2 & 46 & 0,002 & 20,910 & 2,410 & 0,057 & 0,001 \\
\hline
\end{tabular}




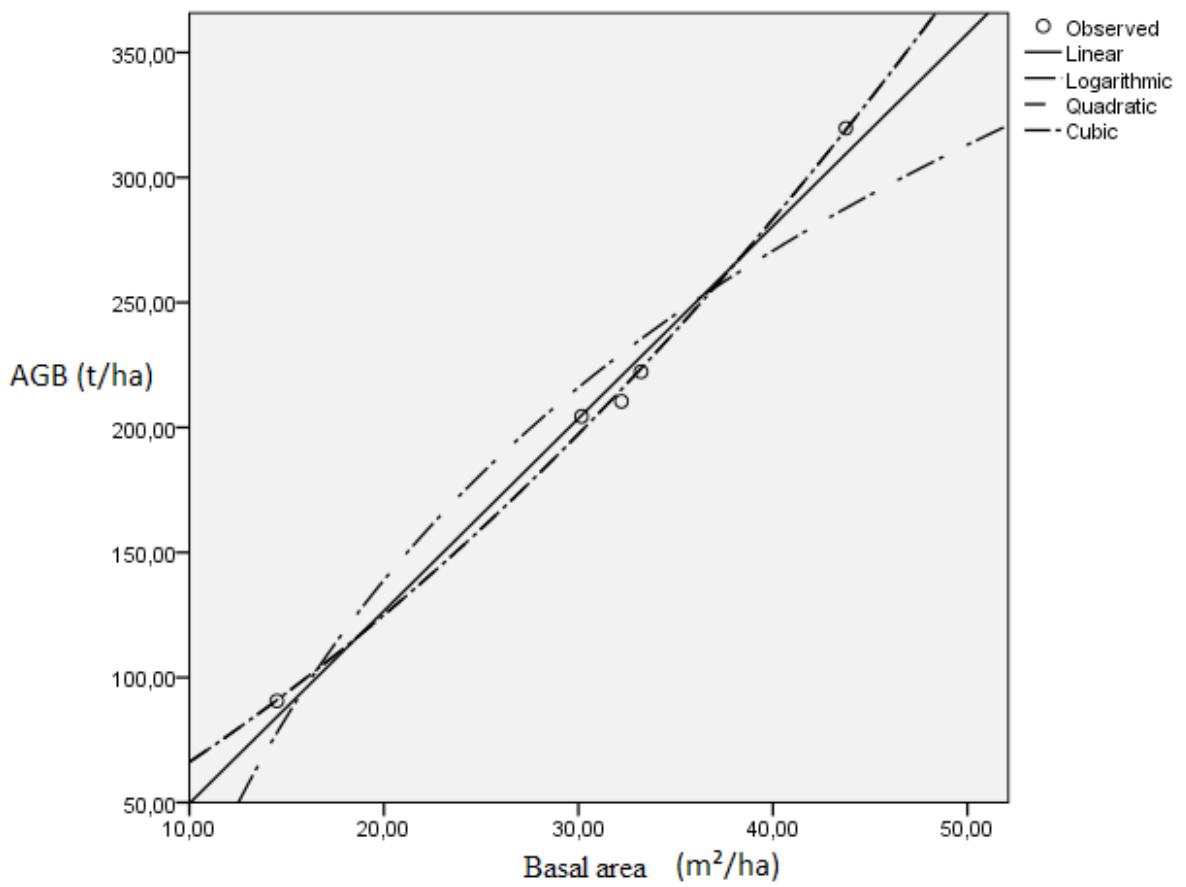

Figure 8. Regression equation curves between AGB and basal area

\section{Discussion}

The results obtained in this study in terms of density are similar to those obtained by Kidikwadi et $a l .{ }^{[28]}$ in the Luki Biosphere Reserve (194 individuals/ha). The Misomuni forest has a large number of plant species density compared to that obtained by $\mathrm{Ngo}^{[29]}$ in the INERA/Kiyaka reserve (density: 5 trees/ha) and those obtained by Kibe ${ }^{[30]}$ in the Ngoso forest. The difference in the results of different studies could be justified by the fact that the present work considered trees with a dbh measured at $1.30 \mathrm{~cm}$ from the ground $\geq 10 \mathrm{~cm}$ which is also a syntaxons made up of small trees and undergrowth shrubs or by habitat fragmentation. The density of the studied stand is high; it is about $1651 \pm 550$ trees/ha. This value of 550 trees/ha is in accordance with those reported by Lejoly ${ }^{[31]}$ in the Ngotto forest and by Masens ${ }^{[21,22]}$ in the forest ecosystems of Kamaba (Kipuka) and Nzundu (Imbongo) in the same region; the forest massif studied is specifically poor and fairly homogeneous. Similar observations had already been made by Kidikwadi et al. ${ }^{[28]}$ and Lubini et $a l .{ }^{[32]}$ who studied respectively the Prioria balsamifera and Hylodendron stand in the Luki reserve and the semi-evergreen rainforest with Celtis milbraedii and Gambeya lacourtiana in the Kikwit region (Zaire/ DRC), and by Pierlot ${ }^{[33]}$ in the Scorodophloeus zenkeri forest (Yangambi, inventory $\mathrm{n}^{\circ} 25$ ). In Zaire, Malaisse ${ }^{[34]}$ inventoried 1463 plants/ha in the dense dry forest; Devineau ${ }^{[35]}$, in Côte d'Ivoire, listed 2884 plants/ha in the Celtis $s p$. forest (Lamto). The results obtained by these authors are highly superior to those observed in the Misomuni forest. This situation can be attributed to the very young age of this phytocenosis.

Among the most abundant trees, Scorodophloeus zenkeri has 50.67 individuals/ha, Staudtia kamerunensis, 39.67 individuals/ha; Anonidium mannii 36.00 individuals/ha, Petersianthus macrocarpus, 28.33 individuals/ha; Maranthes chrysophylla, 21.67 individuals/ha; Brachystegia laurentii, 21.33 individuals/ha; Prioria balsamifera, 20 individuals/ha; Pterocarpus mildbraedii, 19.67 individuals/ha and Tessmannia africana, 18.33 individuals/ha, etc. These results are compatible with those already observed in the same region by Kakiki ${ }^{[36]}$, Masens ${ }^{[22]}$; but superior to those obtained in Kiyaka Forest Reserve by Lula ${ }^{[37]}$; Mungubushi ${ }^{[38]}$. It should also be noted that Gentry ${ }^{[39]}$ obtained densities ranging from 167 to 1947 trees/ha for species with $\mathrm{dbh} \geq 10 \mathrm{~cm}$ in neotropical forest ecosystems. Thus, our results are well within the ranges determined by Rollet ${ }^{[40]}$ for Africa and America and those established by Gentry ${ }^{[39]}$ for neotropical forests.

A value of $183.78 \pm 61.26 \mathrm{t} / \mathrm{ha}$ of AGB was obtained in this forest massif; this value of AGB obtained is largely inferior in comparison with those observed by Sokpon ${ }^{[41]}$ in the various forest stands of Benin. According to this author, the biomass values obtained in these stands vary from 378.8 to $391 \mathrm{t} / \mathrm{ha}$. Synthesizing woody biomass values for moist and semi-deciduous forests, BernhardtVersat et $a l .{ }^{[42]}$, report that woody biomass values range from $233 \mathrm{t} / \mathrm{ha}$ for secondary forests in Ghana to $475 \mathrm{t} / \mathrm{ha}$ for primary forests in Malaya. Edouard and Grubb ${ }^{[43]}$ 
studying dense rainforests in New Guinea obtained biomass values between 330 and $430 \mathrm{t} / \mathrm{ha}$. The low values of AGB, as well as those of basal area $(G)$, obtained in this phytocenosis are attributed to the state of degradation of this forest massif and the scarcity of large trees. Indeed, we numbered 7 emergent with dbh measured at $1.30 \mathrm{~m}$ at breast height and $\geq 40 \mathrm{~cm}$ against 81 trees and shrubs with dbh located between 10 and $39.9 \mathrm{~cm}$. This would prove the immature state of this ecosystem and hence the low values obtained for the relevant parameters. The structure of the studied stand correlates with this assertion (i.e., the distribution of the listed and identified trees in dbh classes).

As shown in the figure for an uneven-aged stand, characterized by trees of all ages and sizes, the distribution of wood numbers by size categories takes the form of a curve with a decreasing trend ${ }^{[4]}$. Referring to the $\mathrm{G}$, Malaisse ${ }^{[13]}$ demonstrated that the $\mathrm{G}$ is a good tool for the classification of earth forma plant formations. He suggested that there is $30-40 \mathrm{~m}^{2} / \mathrm{ha}$ of $\mathrm{G}$ in the Entandrophragma delevoyi dry forest in Zaire (DRC). In the Yapo forest, Bernhard-Reversat et al. ${ }^{[42]}$, estimated 1 $\mathrm{m}^{2} / \mathrm{ha}$ of BA and $30 \mathrm{~m}^{2} /$ ha for the Khade forest (Ghana). When considering the entire area prospected, i.e. 3 ha, the BA value obtained in this study is in the same order of magnitude as those of the authors mentioned above. It is however very low when it is reduced to one hectare. Indeed, the value of BA obtained is $55.18 \pm 18.39 \mathrm{~m}^{2} / \mathrm{ha}$. This is probably due to the rarity of large emergent in this plant community. Indeed, the plant species presenting elevated values of basal area (BA) are also those that produce important quantities of aerial biomass (AGB). Thus, more BA increase, more AGB are important (expressed as $\mathrm{CO}_{2}$ sequestration), it shows that the production of the aerial biomass is linked to the density of the individuals. The protection and the conservation of such a forest massif permits to fight so much against the climatic changes on a local scale (regulation of microclimate) as well as at the regional level.

\section{Conclusions and Suggestions}

The Misomuni forest massif is much floristically diversified ( 88 plant species belonging to 71 genera and 32 families) and plays a significant role in the sequestration of $\mathrm{CO}_{2}$. The total AGB of the inventoried trees is 183.78 $\pm 61.26 \mathrm{t} / \mathrm{ha}$ corresponding to stored carbon and carbon equivalent of $96.63 \pm 32.21 \mathrm{t} / \mathrm{ha}$ and $289.92 \pm 96.64 \mathrm{t} / \mathrm{ha}$ respectively. The protection of this ecosystem is highly needed for combatting climatic changes at local scale and for the conservation biodiversity habitat.

It is therefore a necessity for the Congolese government to establish a partnership with universities and research institutes across the country in order to finance the related themes, and to extend such research within the forest ecosystems, or at least what is left of it in this country, as recommended by the REDD+ program. This would help our country to assert its rights to the payment of the environmental services related to the stock of carbon credit in these types of ecosystems.

\section{Acknowledgements}

The authors are indebted to Alfred Clément Inkoto, Santos Kavumbu, Blaise Mbembo-Wa-Mbembo, Laurent Gbanzo and Peter Mpilembo for their collaboration and assistance.

\section{References}

[1] Ngbolua, K.N., Ngemale, G.M., Masengo, A.C., Motende, B.N., Ndolete, G.J-P., Djolu, D.R., Libwa, M.B. and Bongo, N.G. (2019), Evaluation of Artisanal Logging Sector in Democratic Republic of the Congo: A Case Study of Peri-urban Forest of Gbadolite City, Nord-Ubangi. Int. J. Plant Sci. Ecol., 5(2), 25-30.

[2] Sinsi, B. and Kampmann, D. (Eds) (2010), Atlas de la biodiversité de l'Afrique de l'Ouest. Tome I: Benin. Cotonou \& Frankfurt/Main.

[3] Masens, D.-M.Y.B., Ngbolua, K.N., Briki, K.C. and Muhammad, R. (2021), Survey on the Production of Traditional Bioenergy in the Democratic Republic of the Congo: The Case Study of Kwilu Province. BIoEx Journal 3(2), 84-90.

[4] Ngbolua, K.N., Ndanga, A.A., Gbatea, A., Djolu, R., Ndaba, M., Masengo, C., Likolo, J., Falanga, C., Yangba, S., Gbolo, B. and Mpiana P. (2018), Environmental Impact of Wood-Energy Consumption by Households in Democratic Republic of the Congo: A Case Study of Gbadolite City, Nord-Ubangi. International Journal of Energy and Sustainable Development 3(4), 64-71.

[5] Ngbolua, K.N., Falanga, M.C., Djolu, D.R., Masengo, A.C., Nzamonga, G.A., Bongo, N.G., Gbolo, B.Z., Mudogo, V. and Mpiana P.T. (2019), Socio-economic and Environmental Impacts of Clay Brick Manufacturing in Gbado-Lite City (Nord Ubangi Province, DR Congo). Journal of Environment Protection and Sustainable Development 5(3), 126-131.

[6] Raunkiaer, C. (1934), The life forms of plants and statistical plant geography. Oxford Clarendon Press, p632.

[7] Schmitz, A. (1988), Revision of the described plant groups of Zaire, Rwanda and Burundi, 315p. Publ. 
CIDAI, Mus. Roy. Afr. Centr. Tervuren.

[8] Trochain, J.L. (1980), Plant ecology of the intertropical non-desert zone. Univ. Paul Sabatier Toulouse, France, $\mathrm{p} 468$.

[9] Lubini, A.C. (1997), The vegetation of the Luki Biosphere Reserve in Mayombe (Zaire). Jard. Bot. Nat. Belg. Opera Botanica. Meise, p155.

[10] Habari, M. (2009), Floristic, phytogeographic and phytosociological study of the vegetation of Kinshasa in the Democratic Republic of the Congo. PhD Thesis, University of Kinshasa.

[11] Raunkiaer, C. (1934), The life forms of plants and statistical plant geography. Oxford: Clarendon Press, p.632.

[12] Mullenders, W. (1954), The vegetation of Kaniama (between Lubishi-Lubilash). Publ. INEAC. Sér. Sc. p61.

[13] Malaisse, F. (1984), Contribution to the study of the dense dry forest ecosystem (Muhulu). 4. Structure of a Zambezi dry forest near Lubumbashi (Zaire). Bull. Soc. Roy. Bot. 117, 428-458.

[14] Masens, D.-M.Y.B. (1997), Phytosociological study of the Kikwit region (Bandundu, Zaire). PhD Thesis, U.L.B., Bruxelles, p382.

[15] Mandango, M.A. (1982), Flora and vegetation of the islands of the Zaire River in the Tshopo Sub-Region (Haut-Zaire). PhD Thesis, Faculty of Science : University of Kisangani. Tomes $1 \& 2$, p425.

[16] Dansereau, P. and Lems, K. (1957), The grading of dispesal types in plant communities and their significance. Contrib. Inst. Bot. Montréal (71), 52.

[17] Evrard, C. (1968), Ecological research on the forest stand of hydromorphic soils in the central Congolese basin. Publ. INEAC., sér. Sc. p110.

[18] Mollinier, R. and Müller, P. (1938), The spread of plant species. Rev. Gén. Bot., L., p53-670, passim.

[19] Lebrun, J. (1947), Vegetation of the floodplain south of Lake Edouard. Exp. Parc Nat., Bruxelles, p153.

[20] Lubini, A.C. (2001), Phytogeographic analysis of the forest flora of the Kasai sector in Congo Kinshasa. In: Proceedings of the XVIth plenary meeting of the l'AETFAT, vol. 72 n², Bull. Jard. Bot. Nat. Belg., Bruxelles, p859-872.

[21] Masens, D.-M.Y.B. (2015), Contribution to the phytoecological study of the Kamaba forest (Kipuka, district du Kwilu, province de Bandundu, R. D. Congo) Congo Sci. (online ACASTI \& CEDESURK Journal); $3: 31-32$.

[22] Masens, D.-M.Y.B., Ngbolua, K.N., Tembeni, M.T. and Bongo, N.G. (2017), Phytosociological study of Nzundu massif forest of Imbongo city, Kwilu prov- ince, Democratic Republic of the Congo. Tropical Plant Research 4 (3), 363-375.

[23] Lubini, Q.C. (1982), Messicultural and post-cultivation vegetation in the Kisangani and Tshopo sub-regions (Haut Zaire). PhD Thesis, Faculty of Science: University of Kisangani, p489.

[24] Chave, J., Andalo, C., Brown, S., Cairns, M.A., Chambers, J.A., Eamus, D., Foilster, H., Frormard, F., Higuchi, N., Kira, T., Lescure, J.-P., Nelson, B.W., Ogawa, H., Puig, H., Riera, B. and Yamakura, T. (2005), Tree allometry and improved estimation of carbon stocks and balance in tropical forests. Oecologia $145,87-99$.

[25] Ibrahima, A. and Fanta, A.C. (2008), Estimation of carbon stock in tree and shrub facies in the Sudano-Guinean savannahs of Ngaoundéré, Cameroun. Cameroun Journal of Experim. Biology (4)3, 1-11.

[26] Toung, D. (2010), Estimation of the quantity of carbon stored by a forest under reconstitution. Case of a young fallow in the classified forest of Mondah. MSc Thesis. National School of Water and Water of Cap-Estérias, Gabon.

[27] Lubini, A.C., Belesi, K., Kidikwadi, T. and Kisompa, R. (2014), Preliminary note on the measurement of above-ground biomass and carbon stock in a forest patch in Kinshasa. Congo Sciences 2(2), 114-1119.

[28] Kidikwadi, E.T., Lubini, A.C., Luyindula, N. and Belesi, H. (2015), Preliminary note on the ecology and biomass measurement of Prioria balsamifera in the INERA forest stations of Luki and Kiyaka in DR Congo. International Journal of Innovation and Applied Studies 11(4), 914-927.

[29] Ngo, O. (2015), Contribution to the ecological study of the above ground biomass and carbon sequestration in the INERA/Kiyaka forest. BSc Thesis, ISP Kikwit: Democratic Republic of the Congo.

[30] Kibe, R. (2017). Contribution to the ecological and above ground biomass and carbon sequestration study in Ngoso village forest. BSc Thesis, ISP Kikwit: Democratic Republic of the Congo.

[31] Lejoly, J. (1996). Regional synthesis on the plant biodiversity of woody plants in the 6 sites of the ECOFAC Project in Central Africa, Groupement AGRECO-CTFT. Bruxelles, p81.

[32] Lubini, K.K. (1996). The semi-evergreen rainforest with Celtis mildbraedii and Gambeya lacourtiana in the Kikwit (Zaïre). Bull. Jard. Bot. Nat. Belg. 61, 305-334.

[33] Piélou, E.C. (1996). Species diversity and pattern diversity in study of ecological succession. J. Theor. Biol. 10, 370-383. 
[34] Malaisse, F. (1984), Contribution to the study of the dry dense forest ecosystem (Muhulu). 4. Structure of a dense dry Zambezian Forest near Lubumbashi (Zaire). Bulletin of the Royal Botanical Society of Belgium 117, 428-458.

[35] Devineau, J.L. (1984). Structure and dynamics of some West African tropical forests (Ivory Coast), Stat. Ecol. Trop. Lamto, University of Abidjan, p294.

[36] Kakiki, K. (2015), Contribution to the ecological and aerial study and carbon sequestration in the INERA/ Kiyaka forest. BSc Thesis, ISP Kikwit: Democratic Republic of the Congo.

[37] Lula, M. (2015), Contribution to the ecological and above ground biomass study and carbon sequestration in the INERA/Kiyaka forest. BSc Thesis, ISP Kikwit: Democratic Republic of the Congo.

[38] Mungubushi, N. (2015), Contribution to the ecological study of above ground biomass and carbon sequestration in INERA/Kiyaka forest. BSc Thesis, PSI/Kikwit.
[39] Gentry, A.H. (1982), Patterns of neotropical plant species diversity. In: Hecht M.K., Wallace B., Prance G.T. (eds) Evolutionary Biology. Springer, Boston, MA. https://doi.org/10.1007/978-1-4615-6968-8_1.

[40] Rollet, B. (1974), The architecture of dense lowland evergreen forests. C.T.F.T., Paris, p208.

[41] Sokpon, N. (1995), Ecological research on the dense semi-deciduous forest of Pobe in south-east Benin: Plant groups, structure, natural regeneration and litterfall. PhD Thesis, U.L.B., Bruxelles, p365.

[42] Bernhard-Reversat, C.H. and Lemée G. (1978), The evergreen forest of Lower Cote d'Ivoire. Problem of ecology, Terrestrial ecosystems. Masson. Paris, pp. 313-345.

[43] Edouard, P.J. and Grubb, P.J. (1977), Studies of mineral cycling in a montane rain forest in New Guinea I. The distribution of organic matter in the vegetation and soil. Journal of Ecology 65, 943-969. 